\title{
The avocado subgroup of Phytophthora citricola constitutes a distinct species, Phytophthora mengei sp. nov.
}

\author{
C.X. Hong ${ }^{1}$ \\ Virginia Polytechnic Institute and State University, \\ Hampton Roads Agricultural Research and Extension \\ Center, Department of Plant Pathology, Physiology and \\ Weed Science, 1444 Diamond Springs Road, Virginia \\ Beach, Virginia 23455 \\ M.E. Gallegly \\ West Virginia University, Division of Plant and Soil \\ Sciences, Morgantown, West Virginia 26506 \\ G.T. Browne \\ USDA-ARS, Crops Pathology and Genetics Research \\ Unit, Department of Plant Pathology, University \\ of California, One Shields Avenue, Davis, \\ California 95616 \\ R.G. Bhat \\ University of California, Department of Plant Pathology, \\ One Shields Avenue, Davis, California 95616 \\ P.A. Richardson \\ P. Kong \\ Virginia Polytechnic Institute and State University, \\ Hampton Roads Agricultural Research and Extension \\ Center, 1444 Diamond Springs Road, Virginia Beach, \\ Virginia 23455
}

\begin{abstract}
Isolates from avocado tree cankers have been recognized as a distinct subgroup within the $P$. citricola complex since 1974, both morphologically and molecularly (isozyme and amplified fragment length polymorphism [AFLP] analyses). This subgroup is formally separated from $P$. citricola after comparative DNA fingerprinting and sequence analyses of the ITS region, as well as by morphological examinations. This new taxon is homothallic, produces plerotic oospores with paragynous antheridia and noncaducous semipapillate sporangia. Morphologically it differs from other species of Waterhouse group III by producing many large bizarre-shaped sporangia and smaller oogonia with asymmetric capitate antheridia. It belongs to clade 2 and is phylogenetically closer to $P$. siskiyouensis, $P$. capsici and $P$. tropicalis than to $P$. citricola. $P$. mengei can be easily differentiated from its relatives in the same clade and other species of this morpho-group by DNA fingerprints and sequence analysis. This new taxon is named Phytophthora mengei sp. nov.
\end{abstract}

Accepted for publication 8 May 2009.

${ }^{1}$ Corresponding author. E-mail: chhong2@vt.edu
Key words: avocado canker pathogen, identification, Oomycete

\section{INTRODUCTION}

Among six species of Phytophthora affecting avocado (Persea americana Miller) in USA (Farr et al 1989) $P$. citricola was identified to be the primary cause of trunk canker (Zentmyer 1973, Zentmyer et al 1974). Feeder roots and tree trunks are the primary infection courts (Elhamalawi et al 1995b) although the pathogen may attack main structural roots (Coffey 1987, Zentmyer et al 1974) and fruit (Koike et al 1987, Ouimette et al 1988). The resultant disease is commonly known as "citricola canker" (Elhamalawi et al 1995a). This disease first was described by Fawcett (1916) and Barrett (1917), and it has caused increasing devastation to avocado in California (Coffey et al 1988, Coffey 1987, Elhamalawi and Menge 1994).

Our knowledge about the identity of the causal agent of avocado trunk canker has evolved over time. The pathogen was identified first as a Pythiacystis sp. (Fawcett 1916). A year later it was redescribed as Phytophthora cactorum (Lebert and Cohn) J. Schrot. (Barrett 1917). Phytophthora citricola was separated from P. cactorum by Sawada (Sawada 1927, Tucker 1931). The avocado canker pathogen subsequently was identified as Phytophthora citricola Sawada based on its similarity in morphology and protein banding patterns with those of other isolates of $P$. citricola (Zentmyer 1973, Zentmyer et al 1974). While identifying the pathogen as $P$. citricola, Zentmyer and associates clearly acknowledged that the avocado canker pathogen produced smaller oogonia and oospores than did the type culture of this species. Also the avocado isolates more frequently produced irregular sporangia in greater variety than the type culture of $P$. citricola (Zentmyer et al 1974). This pathogen more recently was demonstrated to belong to a subgroup within $P$. citricola based on distinct patterns of isozymes (Oudemans et al 1994) and amplified fragment length polymorphisms (AFLP) (Bhat and Browne 2007).

The above morphological and molecular differences indicate that the avocado canker pathogen is a separate species. To test this hypothesis we performed a standard DNA fingerprinting technique based on single-stranded conformation polymorphism of PCR- 
amplified ribosomal DNA (PCR-SSCP) (Gallegly and Hong 2008). This technique was developed by Kong and associates (2003) and since has been evaluated with the vast majority of the known species of Phytophthora (Hong et al unpubl data). Each different PCR-SSCP, with a few exceptions, represent a distinct species within the genus (Gallegly and Hong 2008; Kong et al 2003, 2004a). We also sequenced representative isolates and examined their morphology. This paper reports on the morphology, DNA fingerprint and sequence analysis data of this new taxon in comparison with morphologically similar species.

\section{MATERIALS AND METHODS}

Isolation and isolate maintenance.-All cultures of the new taxon examined in this study were collected from the trunk of avocado trees in southern California. Nine of the isolates, including the type culture, were isolated by Dr John Menge of the University of California at Riverside (TABLE I). Single zoospore isolates of these cultures were obtained as described by Bhat and Browne (2007), and they were grown on V8 juice agar (Erwin and Ribeiro 1996). Blocks of fresh agar cultures were transferred into microtubes with sterile distilled water for long-term storage at $15 \mathrm{C}$. Five additional cultures representing several known species with similar morphology also were included in this study for comparison purposes.

Morphology.-Among the 11 isolates of the avocado trunk canker pathogen whose SSCP DNA fingerprints were identical, two (p340, p341) were selected for morphology studies. The detailed procedures are presented on pages 6 and 15 in Gallegly and Hong (2008). Sporangia were produced on disks of lima bean agar in $10 \%$ sterile soil extract under fluorescent light at 20-22 C. Hemp-seed agar was used for production of the sexual organs. About 20 measurements were made of each morphological stage. Microphotographs of the organs were made with Kodak Professional T-Max $10035 \mathrm{~mm}$ film (Eastman Kodak Co., Rochester, New York) with $43 \times$ and $97 \times$ objectives of a Bausch \& Lomb zoom microscope. Black and white negatives were converted to positive digital images with a Polaroid $35 \mathrm{~mm}$ scanner using Photoshop.

Physiology.-The two isolates (p340, p341) used in the morphology studies were incubated at $6,10,15,20,25,28$, 30, 33 and 35 C. Disks (4 mm diam) from $3 \mathrm{~d}$ old cultures were placed on lima bean agar in $60 \mathrm{~mm}$ Petri dishes, and diameters of colony growth were recorded after $2 \mathrm{~d}$.

DNA extraction.- Isolates were grown in V8 juice broth as described in the Appendix to Chapter 3, Growth media and method (Erwin and Ribeiro 1996) at room temperature (ca. $23 \mathrm{C}$ ) for $10 \mathrm{~d}$. DNA was extracted from each culture as instructed with the DNeasy ${ }^{\circledR}$ Plant Minikit (QIAGEN, Valencia, California).

DNA fingerprinting.-A standard fingerprinting (Gallegly and Hong 2008; Kong et al 2003, 2004a) was used. The only modification was that a smaller volume $(2 \mu \mathrm{L})$ denatured
PCR product was loaded for electrophoresis. In addition to the 11 isolates from avocado the type culture and another authentic culture (CBS 295.29) of P. citricola, one isolate each of $P$. primulae Tomlison, $P$. pseudosyringae T. Jung \& Delatour and $P$. syringae (Klebahn) Klebahn (Gallegly and Hong 2008) were included for comparison (TABLE I).

DNA sequencing and sequence analysis. - Two isolates from avocado were sequenced in four nuclear and mitochondrial DNA regions. The ITS regions were amplified with forward primer ITS6 (Cooke et al 2000) and reverse primer ITS4 (White et al 1990). Genes encoding $\beta$-tubulin, translation elongation factor $1 \alpha$ and NADH dehydrogenase subunit I were amplified as described by Kroon et al (2004). Excess primer and dNTP were removed from quantified PCR products with shrimp alkaline phosphatase and exonuclease I (USB Catalog Nos. 70092Y, 70073Z). One unit of each enzyme was added to $15 \mu \mathrm{L}$ PCR product, incubated at $37 \mathrm{C}$ for $30 \mathrm{~min}$, followed by heat inactivation at $65 \mathrm{C}$ for $15 \mathrm{~min}$. Sequencing was performed in both directions for all regions with the same primers as for PCR by the University of Kentucky Advanced Genetic Technologies Center (Lexington, Kentucky). Sequencing was repeated at least once.

Sequences from different runs were compared with the Clustal W multiple sequence alignment at http://align. genome.jp. The consensus sequence of each isolate was aligned with those from other isolates to examine interisolate sequence variation. Basic local alignment search tool (BLASTn, http://ncbi.nlm.nih.gov) was used to identify the closest relatives of $P$. mengei at the respective regions. The phylogenic analyses with a group of selected species was carried out in TOPALI 2.5 (Milne et al 2009) with the Felsenstein-84 nucleotide substitution plus gamma rates heterogeneity model to calculate pair-wise distances, resulting in a neighbor joining tree. A total of 21 other species representing major clades (Blair et al 2008, Cooke et al 2000, Kroon et al 2004, Martin and Tooley 2003) of genus Phytophthora were selected based on the availability of type culture sequence. These sequences were published by Cooke and associates (2000) and by species authorities of P. alni subsp. alni and P. inundata (Brasier et al 2004, Brasier et al 2003), P. bisheria (Abad et al 2008), P. melonis (Ho et al 2007), P. quercetorum (Balci et al 2008) and $P$. siskiyouensis (Reeser et al 2007). Sequences of other sources were double-checked by sequencing the type culture in our collection to confirm its accuracy. Several species of Cooke's clade 2 were included.

\section{TAXONOMY}

Phytophthora mengei G.T. Browne, M.E. Gallegly \& C.X. Hong, sp. nov.

MycoBank MB 513047

Species nova homothallica, laevi-tunicata, faciliter in agaro "lima bean" dicto oogonia globosa numero medio $24.0 \mu \mathrm{m}$ diam formans. Oosporae pleroticae parietibus $2.3 \mu \mathrm{m}$ crassis, numero medio $21.7 \mu \mathrm{m}$ diam. Antheridia claviformia ad vel prope stipitem oogonialem affixa. Antheridia admodum rotundata $(9.3 \times 9.9 \mu \mathrm{m})$. Sporangia non caduca semipapillata, saepe in formis monstruosis sed 
Hong ET AL: PHYTOPHTHORA MENGEI SP. NOV.

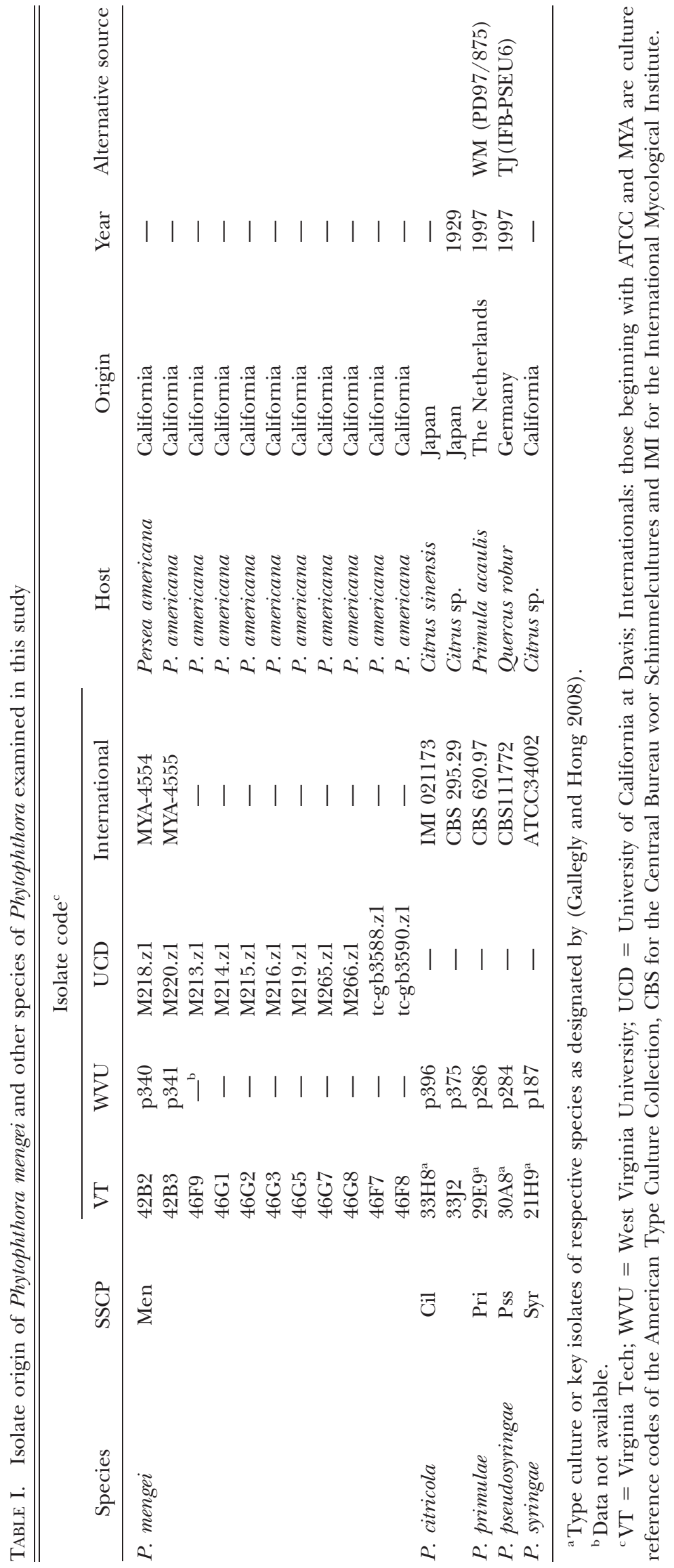


saepissime formis ovoideis, obpyriformibus ellipsoideisque apparentia. Sympodia simplicia in agaro laxa. Magnitudo sporangialis numero medio $62.7 \times 35.2 \mu \mathrm{m}$ (in mensura tota $37.4-78.2 \times 27.2-44.2 \mu \mathrm{m})$, ratione arithmetica longitudinis usque latitudinis 1.8. Partes inflatae hyphales atque chlamydoposporae nullae. Temperatura maxima ad incrementum coloniale 30-32 C.

Holotypus: ATCG MYA 4554.

Phytophthora mengei G.T. Browne, M.E. Gallegly \& C.X. Hong, sp. nov.

Phytophthora mengei is homothallic and forms sex bodies readily in lima bean and hemp-seed agars (FIG. 1). The oogonia average $24.0 \mu \mathrm{m}$ diam (range 20.4-27.2 $\mu \mathrm{m}$ ) and some have tapered stalks, sometimes with a slight hook in the taper. Oospores are mostly plerotic with $2.3 \mu \mathrm{m}$ thick walls (range $1.5-$ $3.0 \mu \mathrm{m}$ ) and average $21.7 \mu \mathrm{m}$ diam (range 18.7$24.5 \mu \mathrm{m})$. Oospores in tapered oogonia appear aplerotic as the taper draws away from the round oospores. The diclinous antheridia are paragynous and commonly asymmetrically capitate (FIG 1B). The end of the club is approximately $10 \mu \mathrm{m}$ diam. On tapered oogonia the antheridia are located on the taper, commonly at the bottom. When placed in water or soil extract, mycelia on lima bean agar disks from $3 \mathrm{~d}$ old cultures form abundant semipapillate sporangia in fewer than $8 \mathrm{~h}$ under fluorescent light at room temperature. The apical thickened area is $2.4-3.4 \mu \mathrm{m}$ deep. Bizarre shapes of sporangia occur (sickle, boomerang, sombrero and bluntly ellipsoid). Bluntly ellipsoid sporangia, sometimes with a constriction in the middle, average about $95 \times 35 \mu \mathrm{m}$. Smaller ovoid sporangia are about $49 \times 34 \mu \mathrm{m}$. Overall sporangia average $62.7 \times 35.2 \mu \mathrm{m}$ (range $37.4-95.0 \times 27.2-$ $44.2 \mu \mathrm{m})$. The length to width ratio is 1.8 . Width of the papillae pores vary, 6.6-13.5 $\mu \mathrm{m}$. Sporangia are noncaducous. Also a few sporangia are formed on lima bean agar where they are mostly ovoid and of about the same size as the ovoid ones formed in water, but those formed in agar sometimes appear to be papillate. Empty sporangia have a small plug at the point of pedicel attachment. Simple sympodia occur but sometimes a single sporangium on a long pedicel is seen. Hyphal swellings and chlamydospores have not been seen, but knobby hyphae are common.

HOLOTYPE: ATCC MYA-4554 here designated; a cryopreserved specimen of M218.z1 originally isolated from Persea americana by J. Menge (USA, California). GenBank EU748545.

\section{Additional strains examined.-TABLE II.}

Etymology._- "mengei" refers to the originator (Dr John Menge) of the type culture and eight additional avocado isolates used in this study.

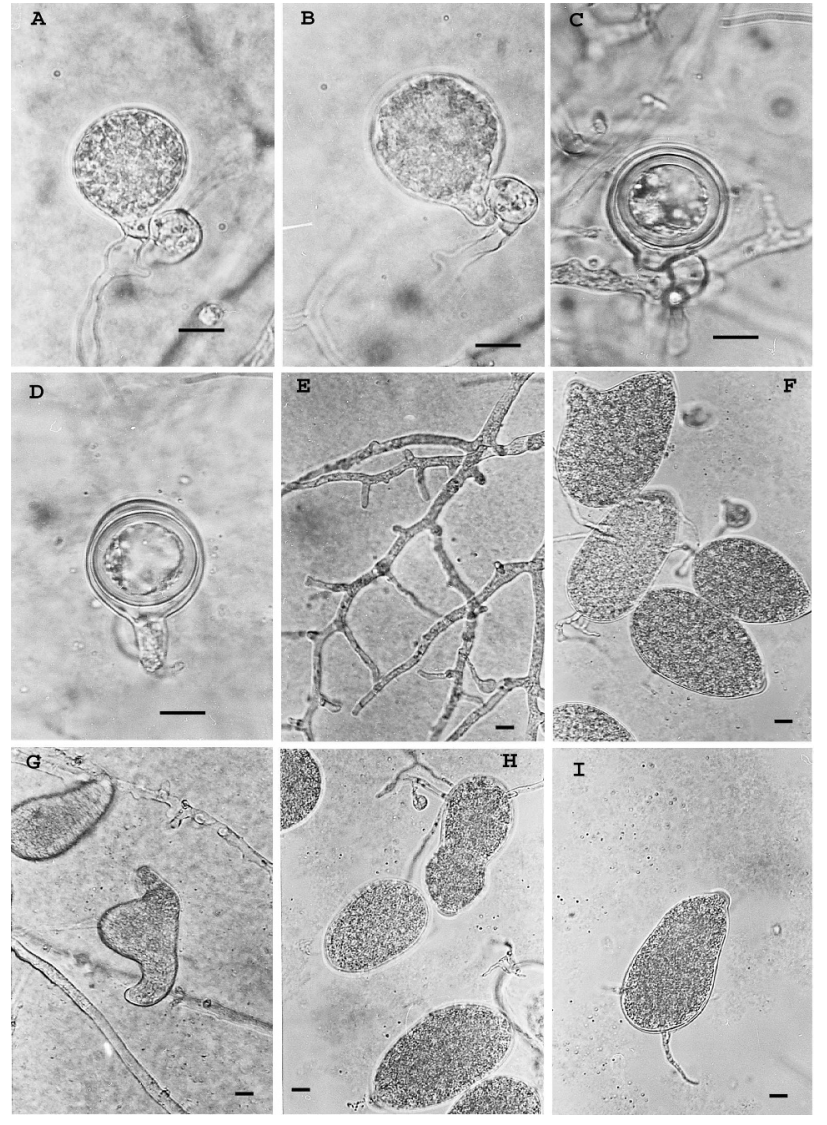

FIG. 1. Diagnostic morphological characters of Phytophthora mengei. A, B. Young oogonia and antheridia showing asymmetric capitate antheridia. C, D. Mature sexual bodies with plerotic oospores. E. Hyphae with knobs and short projections. F. Ovoid and bluntly ellipsoid semipapillate sporangia, one with two papillae. G. A bizarre sombrero-shaped sporangium. H. Ellipsoid sporangia, one with a constriction. I. A single bluntly ellipsoid sporangium. Bars $=10 \mu \mathrm{m}$.

Habitat. - This pathogen is found in the trunks, main structural roots and fruit of infected avocado trees in southern California, USA.

\section{RESULTS}

Temperature-growth relation.-Daily growth rates on lima bean agar for p340 and p341 were respectively $0 \mathrm{~mm}$ at 6,33 and $35 \mathrm{C}, 5 \mathrm{~mm}$ at $10 \mathrm{C}, 5$ and $8 \mathrm{~mm}$ at $15 \mathrm{C}, 13$ and $11 \mathrm{~mm}$ at $20 \mathrm{C}, 15$ and $13 \mathrm{~mm}$ at $25 \mathrm{C}$, $6 \mathrm{~mm}$ at $28 \mathrm{C}$ and $5 \mathrm{~mm}$ at $30 \mathrm{C}$. Thus the minimum temperature for colony growth was 6-10 C, the optimum about $25 \mathrm{C}$, and the maximum 30-33 C.

SSCP analysis. - The 11 isolates of $P$. mengei produced an identical PCR-SSCP pattern that was distinct from four reference species (FIG. 2). Comparatively both top and bottom bands of $P$. mengei were faster 
Hong ET AL: PHYTOPHTHORA MENGEI SP. NOV.

TABLE II. Morphological characters of Phytophthora mengei and other homothallic-paragynous-semipapillate species of Phytophthora

\begin{tabular}{|c|c|c|c|c|c|c|}
\hline & P. mengei & P. citricola & P. primulae $I$ & P. pseudosyringae & P. siskiyouensis & P. syringae \\
\hline $\begin{array}{l}\text { Number of isolates or } \\
\text { reference }\end{array}$ & 11 & 2 & $\begin{array}{l}\text { (Gallegly and } \\
\text { Hong 2008) }\end{array}$ & $\begin{array}{l}\text { (Gallegly and } \\
\text { Hong 2008) }\end{array}$ & $\begin{array}{l}\text { (Reeser et al } \\
\text { 2007) }\end{array}$ & $\begin{array}{l}\text { (Gallegly and } \\
\text { Hong 2008) }\end{array}$ \\
\hline Oogonium $(\mu \mathrm{m})$ & 26 & 31 & 38 & 30 & 27.8 & 28 \\
\hline Antheridia & 10 & 10.5 & 14 & 10 & $8.6-11.6 \times 9.5-13.3$ & 10 \\
\hline \multicolumn{7}{|l|}{ Oospore } \\
\hline Fitness & Plerotic & Plerotic & Aplerotic & Plerotic & Aplerotic & Plerotic \\
\hline Mean diameter $(\mu \mathrm{m})$ & 22 & 28 & 30 & 27 & 24.6 & 26 \\
\hline $\begin{array}{l}\text { Diameter range } \\
\qquad(\mu \mathrm{m})\end{array}$ & - & - & $25.5-34.0$ & - & $22.5-25.8$ & - \\
\hline Wall thickness $(\mu \mathrm{m})$ & 2.3 & 1.5 & 2.5 & 1.0 & - & 4.0 \\
\hline \multicolumn{7}{|l|}{ Sporangia } \\
\hline $1 \times \mathrm{w}$ mean $(\mu \mathrm{m})$ & $62.7 \times 35.2$ & $56.3 \times 37.8$ & $57.1 \times 44.8$ & $40.8 \times 30.6$ & $55 \times 36$ & $42.0 \times 31.0$ \\
\hline $1 \times w$ range & $37-95 \times 27-44$ & $35-78 \times 27-49$ & $53-65 \times 39-48$ & $37-42 \times 26-33$ & $46-70 \times 30-51$ & $30-56 \times 22-37$ \\
\hline $1 / \mathrm{w}$ ratio & 1.78 & 1.48 & $1.26 \mathrm{a}$ & 1.44 & 1.5 & 1.35 \\
\hline Caducity $^{\mathrm{b}}$ & - & - & - & - & + & - \\
\hline Hyphal swelling ${ }^{c}$ & - & + & ++ & + & - & + \\
\hline \multicolumn{7}{|l|}{$\begin{array}{l}\text { Temperature-growth } \\
\text { relation }\end{array}$} \\
\hline Maximum (C) & $30-33$ & 31 & $<27$ & $<27$ & 30 & 23 \\
\hline Optimum (C) & 25 & $25-28$ & $15-20$ & 20 & 25 & $15-20$ \\
\hline $\begin{array}{l}\text { Growth rate at } \\
\text { optimum }\left(\mathrm{mm} \mathrm{d}^{-1}\right)\end{array}$ & 14.5 & 一 & 一 & 4.6 & $6.2-8.5$ & - \\
\hline Phylogenetic clade $^{\mathrm{d}}$ & 2 & 2 & 8 & 3 & 2 & 8 \\
\hline
\end{tabular}

${ }^{\text {a }}$ Only ovoid sporangia measured, bizarre sporangia up to $300 \mu \mathrm{m}$ occasionally occur.

$\mathrm{b}-=$ non-caducous, $+=$ caducous.

${ }^{\mathrm{c}}-=$ not present, $+=$ not common, $++=$ common .

${ }^{\mathrm{d}}$ According to Cooke et al (2000).

moving than bands of the other Phytophthora spp. used as references.

Sequence analysis and phylogenetic position of P. mengei.-Both isolates of $P$. mengei had identical complete sequences in ITS1-5.8S-ITS2 region of rDNA (EU748545, EU748546, $753 \mathrm{bp}$ ), and partial sequences of $\beta$-tubulin gene (899 bp), translation elongation factor $1 \alpha(869 \mathrm{bp})$ and NAHD dehydrogenase subunit I (792 bp). Sequence alignments of the ITS regions indicated that this new species is clustered with $P$. botryosa Chee, $P$. colocasiae Racib. and $P$. meadii. McRae (FIG. 3). Phylogenetically this species is closer to $P$. siskiyouensis Reeser and E.M. Hansen, $P$. capsici Leonian, P. tropicalis Aragaki and J.Y. Uchida than $P$. citricola. Compared to $P$. siskiyouensis $P$. mengei has two insertions at sites 108 and 406 , one deletion at 15 and five substitutions at 136, 143, 401, 531 and 689 respectively. Similarly this new species has one insertion at site 400 and seven substitutions at 94, 96, 124, 142, 419, 725 and 737 when compared to $P$. tropicalis. In contrast $P$. mengei differs from $P$. citricola by having a long gap at sites 59-69, three insertions at 414, 415 and 730 and nine substitutions at 58, 70, 133, 134, 153, 411, 429, 443 and 748 respectively. Sequence alignments of the other three regions (data not shown) support the phylogenetic analysis of the ITS region.

\section{DISCUSSION}

Comparative DNA fingerprinting and sequence analyses, as well as morphological examinations, indicated that the avocado subgroup of $P$. citricola constitutes a new, separate species, and we named it Phytophthora mengei sp. nov. This new species is phylogenetically closer to $P$. siskiyouensis, $P$. capsici and $P$. tropicalis than $P$. citricola. Separation of $P$. mengei from $P$. citricola is supported by studies of morphology (Zentmyer et al 1974), isozymes (Oudemans et al 1994) and AFLP (Bhat and Browne 2007). Phytophthora mengei can be easily differentiated from its close relatives by sequence analysis. Also it can be easily distinguished from these relatives and other 


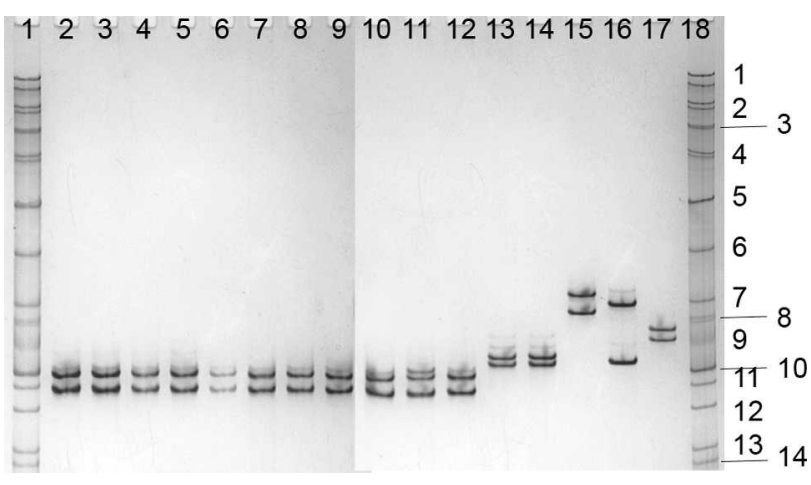

FIG. 2. Polyacrylamide gel electrophoresis of amplified ribosomal DNA internal transcribed spacer 1 region with primers ITS6 and ITS7 of 11 isolates of Phytophthora mengei (Lanes 2-12) and two authentic isolates of Phytophthora citricola (Lanes 13 and 14) and one isolate of P. syringae, $P$. primulae and $P$. pseudosyringae (Lanes $15-17$ respectively). Lanes 1 and 18 are single-stranded DNA (ssDNA) ladders.

morphologically similar species of Waterhouse group III by DNA fingerprints (Gallegly and Hong 2008; Kong et al 2003, 2004a, b).

Phytophthora mengei will be placed in the homothallic-paragynous-semipapillate group of the mor- phological key by Gallegly and Hong (2008). The other species in this group are $P$. citricola, $P$. syringae, $P$. pseudosyringae, $P$. primulae and $P$. porri. Based on its original description $P$. siskiyouensis will be placed in this group. The differences of these species are that $P$. mengei has smaller oogonia, no hyphal swellings, and has asymmetric capitate antheridia on many of the oogonia. The sporangia of $P$. mengei are similar to those of $P$. primulae and differ from those of the other species in the group by forming many large, bizarre shapes. However the oogonia of $P$. mengei are much smaller than those of $P$. primulae $(24 \mathrm{vs} .38 \mu \mathrm{m})$ and the maximum temperature for colony growth is higher (31 vs. $<27 \mathrm{C}$ ). This new species also can be easily separated from $P$. capsici and $P$. tropicalis. Phytophthora mengei is homothallic and produces noncaducous semipapillate sporangia, whereas $P$. capsici and P. tropicalis are heterothallic and produce conspicuously papillate sporangia. In addition sporangia of $P$. tropicalis are caducous with long pedicels.

$P$. mengei and $P$. siskiyouensis are mostly similar morphologically. The oospores of $P$. mengei are plerotic, whereas those of $P$. siskiyouensis are aplerotic. Also the oogonial sizes of these two species differ

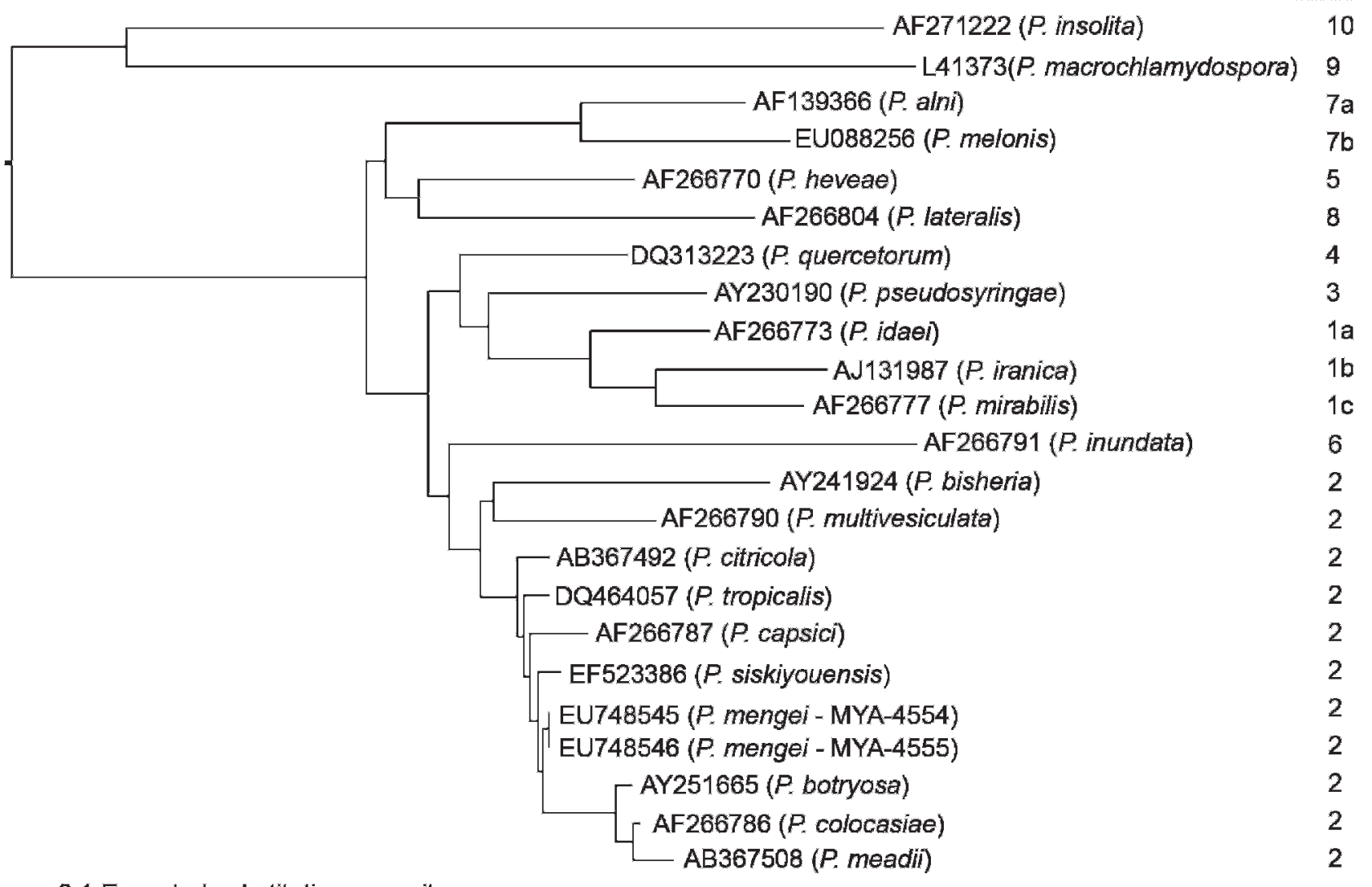

\subsection{Expected substitutions per site}

FIG. 3. Neighbor joining phylogenetic tree based on the sequences of the ITS regions of Phytophthora mengei with its close relatives and other species representing different clades of genus Phytophthora. 
slightly ( $26.0 \mathrm{vs.} 27.8 \mu \mathrm{m})$. The antheridia of $P$. mengei and those of $P$. siskiyouensis are described respectively as being asymmetrically capitate and capitate. Also sporangia of these two species are similar but those of $P$. mengei appear to be more irregularly shaped. The maximum growth temperature for $P$. mengei is slightly higher than that for $P$. siskiyouensis, whereas the minimum temperature for growth is lower for $P$. siskiyouensis. Variability among isolates of these two species could render the above discussion moot.

\section{ACKNOWLEDGMENTS}

We thank Dr Patricia M. Eckel at the Missouri Botanical Garden, St Louis, Missouri, for her assistance in preparing the Latin diagnosis.

\section{LITERATURE CITED}

Abad ZG, Abad JA, Coffey MD, Oudemans PV, Man WA, de Gruyter H, Cunnington J, Louws FJ. 2008. Phytophthora bisheria sp nov., a new species identified in isolates from the Rosaceous raspberry, rose and strawberry in three continents. Mycologia 100:99-110.

Balci Y, Balci S, Blair JE, Park SY, Kang S, Macdonald WL. 2008. Phytophthora quercetorum sp nov., a novel species isolated from eastern and north-central USA oak forest soils. Mycol Res 112:906-916.

Barrett JT. 1917. Pythiacystis related to Phytophthora. Phytopathology 7:150.

Bhat RG, Browne GT. 2007. Genetic diversity in populations of Phytophthora citricola associated with horticultural crops in California. Plant Disease 91:1556-1563.

Blair JE, Coffey MD, Park SY, Geiser DM, Kang S. 2008. A multi-locus phylogeny for Phytophthora utilizing markers derived from complete genome sequences. Fungal Genet Biol 45:266-277.

Brasier CM, Kirk SA, Delcan J, Cooke DEL, Jung T, Man in't Veld WA. 2004. Phytophthora alni sp. nov. and its variants: designation of emerging heteroploid hybrid pathogens spreading on alnus trees. Mycol Res 108:1172-1184.

_ Sanchez-Hernandez E, Kirk SA. 2003. Phytophthora inundata sp. nov., a part heterothallic pathogen of trees and shrubs in wet or flooded soils. Mycol Res 107: 477-484.

Coffey M, Oudemans PV, Ouimette D. 1988. Phytophthora citricola: another cause of avocado decline. Calif Avocado Soc Yearbook 72:127-131.

- 1987. Phytophthora root-rot of avocado-an integrated approach to control in California. Plant Disease 71:1046-1052.

Cooke DEL, Drenth A, Duncan JM, Wagels G, Brasier CM. 2000. A molecular phylogeny of Phytophthora and related oomycetes. Fungal Genet Biol 30:17-32.

Elhamalawi ZA, Menge JA. 1994. Avocado trunk canker disease caused by Phytophthora citricola-investigation of factors affecting infection and disease development. Plant Disease 78:260-264. $\longrightarrow$ - $\longrightarrow$ Adams CJ. 1995a. Methods of fosetyl-Al application and phosphonate levels in avocado tissue needed to control stem canker caused by Phytophthora citricola. Plant Disease 79:770-778.

- - - Guillemet FB. 1995b. Infection court and factors affecting the expansion of stem canker of avocado caused by Phytophthora citricola. Plant Disease 79:384-388.

Erwin DC, Ribeiro OK. 1996. Phytophthora diseases worldwide. St Paul, Minnesota: APS Press. 562 p.

Farr DF, Bills GF, Chamuris GP, Rossman AY. 1989. Fungi on plants and plant products in the United States. St Paul, Minnesota: APS Press. 1252 p.

Fawcett HS. 1916. A bark disease of avocado trees. Avocado Assoc Annu Rep 1916:152-154.

Gallegly ME, Hong CX. 2008. Phytophthora: Identifying species by morphology and DNA fingerprints. St Paul, Minnesota: APS Press. 158 p.

Ho HH, Gallegly ME, Hong CX. 2007. Redescription of Phytophthora melonis. Mycotaxon 102:339-345.

Koike ST, Ouimette DG, Coffey MD. 1987. First report of avocado fruit rot caused by Phytophthora citricola in California. Plant Disease 71:1045.

Kong P, Hong CX, Richardson PA, Gallegly ME. 2003. Single-strand-conformation polymorphism of ribosomal DNA for rapid species differentiation in genus Phytophthora. Fungal Genet Biol 39:238-249.

-, Tooley PW, Ivors K, Garbelotto M, Richardson PA. 2004a. Rapid identification of Phytophthora ramorum using PCR-SSCP analysis of ribosomal DNA ITS-1. Lett Appl Microbiol 38:433-439.

— Single-strand conformational polymorphism analysis of the ribosomal internal transcribed spacer 1 for rapid species identification within the genus Pythium. FEMS Microbiol Lett 240:229-236.

Kroon L, Bakker FT, van den Bosch GBM, Bonants PJM, Flier WG. 2004. Phylogenetic analysis of Phytophthora species based on mitochondrial and nuclear DNA sequences. Fungal Genet Biol 41:766-782.

Martin FN, Tooley PW. 2003. Phylogenetic relationships among Phytophthora species inferred from sequence analysis of mitochondrially encoded cytochrome oxidase I and II genes. Mycologia 95:269-284.

Milne I, Lindner D, Bayer M, Husmeier D, McGuire G, Marshall DF, Wright F. 2009. TOPALI v2: a rich graphic interface for evolutionary analyses of multiple alignments on HPC clusters and multi-core desktops. Applications Note 25:126-127.

Oudemans P, Forster H, Coffey MD. 1994. Evidence for distinct isozyme subgroups within Phytophthora citricola and close relationships with $P$. capsici and $P$. citrophthora. Mycol Res 98:189-199.

Ouimette D, Koike S, Coffey M. 1988. Pathogenicity of isolates of Phytophthora citricola from different hosts on unripe fruit of avocado. Calif Avocado Soc Yearbook 72:249-254.

Reeser PW, Hansen EM, Sutton W. 2007. Phytophthora siskiyouensis, a new species from soil, water, myrtlewood (Umbellularia californica) and tanoak (Lithocarpus 
desifloorus) in southwestern Oregon. Mycologia 99:639643.

Sawada K. 1927. Descriptive catalogue of the Formosan fungi III. Rep Dept Agric Res Inst Formosa. 27, 73 p. (In Japanese) (Cited by Tucker, 1931).

Tucker CM. 1931. Taxonomy of the genus Phytophthora de Bary. University of Missouri Agric Experiment Station Res Bull 153. 208 p.

White TJ, Bruns T, Lee S, Taylor J. 1990. Amplification and direct sequencing of fungal ribosomal RNA genes for phylogenetics. In: Innis MA, Gelfand DH, Sninsky JJ, White TJ, eds. PCR protocols: a guide to methods and application. San Diego: Academic Press. p 315322.

Zentmyer GA. 1973. Another species of Phytophthora on avocado in California. Calif Avocado Soc Yearbook 56: $125-129$.

, Jefferson L, Hickman CJ, Yung CH. 1974. Studies of Phytophthora citricola, isolated from Persea americana. Mycologia 66:830-845. 